\title{
KECEMASAN BERKOMUNIKASI PADA MAHASISWA JURUSAN AKUNTANSI POLITEKNIK NEGERI MEDAN
}

\author{
David N. C. Sitompul \\ Universitas Sumatera Utara \\ divadnoslencens@yahoo.com
}

\begin{abstract}
Abstrak
Kompetensi yang memadai terutama dalam berkomunikasi dengan level kecemasan berkomunikasi yang rendah, bahkan tidak cemas sangat mendukung dalam menghadapi persaingan dalam masyarakat global. Kecemasan berkomunikasi akan berpengaruh negatif dalam kehidupan. Tujuan penelitian ini adalah untuk mengetahui pengaruh jenis kelamin, umur, dan tingkat perkuliahan terhadap kecemasan berkomunikasi pada mahasiswa jurusan akuntansi Politeknik Negeri Medan. Pengumpulan data menggunakan kuesioner Personal Report of Communication Apprehension (PRCA). Metode penelitian yang digunakan adalah kuantitatif dengan pendekatan korelasional. Setelah melakukan uji korelasional diketahui bahwa $F_{\text {hitung }}$ sebesar 1,325 dengan tingkat signifikansi 0,266. Ini menunjukkan bahwa signifikansi hitung > signifikansi penelitian, maka tidak ada pengaruh jenis kelamin, umur dan tingkat perkuliahan terhadap kecemasan berkomunikasi pada mahasiswa jurusan akuntansi Politeknik Negeri Medan.
\end{abstract}

Kata Kunci: kecemasan berkomunikasi, PRCA

\begin{abstract}
Adequate competence, especially in communicating with a low level of apprehension, even not apprehensive, is very important in facing competition of global society. Communication apprehension would affect negatively in life. The purpose of this study is to determine the influence of gender, age, and years study to communication apprehension of accounting at Medan State Polytechnic. Data collected by using Personal Report of Communication Apprehension (PRCA questionnaires). The method used in this study was quantitative method with correlation approach. Correlational analysis showed $F=1.325$ with a significance level of 0.266. This means that significance arithmetic> significance of the research. Therefore, there is no influence of gender, age and grade of years study to communication apprehension of accounting students at Medan State Polytechnic.
\end{abstract}

Keywords: communication apprehension, PRCA

\section{PENDAHULUAN}

Manusia sebagai mahluk sosial akan selalu berhubungan dengan manusia lain. Meski teknologi memungkinkan manusia berkomunikasi secara tertulis, namun tuntutan untuk bertemu berkomunikasi secara lisan dan secara langsung akan tetap ada. Ini memperlihatkan bahwa komunikasi secara lisan memiliki nilai yang tidak tergantikan.
Komunikasi secara lisan akan mengalami hambatan bila timbul perasaan cemas atau adanya kecemasan berkomunikasi.

Kecemasan

berkomunikasi menyebabkan ketidakmauan untuk berkomunikasi atau menghindari komunikasi lisan (Matsuoka dan Rahimi, 201:898), lupa apa yang akan dibicarakan, sering melakukan kesalahan dalam 
berbicara, dan sulit berkonsentrasi (Geçer dan Gümüş, 2010:308).

Kompetensi yang memadai terutama dalam berkomunikasi dengan level kecemasan berkomunikasi yang rendah bahkan tidak cemas sangat mendukung dalam menghadapi persaingan masyarakat ekonomi ASEAN, karena jika lulusan perguruan tinggi memiliki level kecemasan berkomunikasi yang tinggi akan sulit untuk menyampaikan pesan untuk menghadapi persaingan dalam masyarakat ekonomi ASEAN. Adapun delapan profesi yang terbuka pada masyarakat ekonomi ASEAN antara lain insinyur, perawat, arsitek, pekerja di pariwisata, medis, dosen, dokter gigi, dan akuntan (beritasatu.com, 26 Maret 2014).

Penelitian mengenai kecemasan berkomunikasi masih sedikit di Universitas Sumatera Utara. Menurut data repository.usu.ac.id per Maret 2016, baru ada dua penelitian mengenai kecemasan berkomunikasi yang dilakukan pada program sarjana ilmu komunikasi dan satu penelitian yang dilakukan pada program magister ilmu komunikasi pada Universitas Sumatera Utara.

Beberapa penelitian mengenai kecemasan berkomunikasi yang dilakukan pada program sarjana ilmu komunikasi berjudul "Fenomena Komunikasi Antarpribadi Dosen Pembimbing dan Mahasiswa Dalam Bimbingan Skripsi (Studi Kasus Kecemasan Berkomunikasi dan Ketidakpastian Pada Mahasiswa FISIP USU)" yang ditulis oleh Silitonga (2011) dan "Kecemasan Berkomunikasi Antarpribadi dan Cara Mengatasinya (Studi Deskriptif Mengenai Kecemasan Pelamar Kerja Dalam Tes Wawancara Kerja dan Cara Mengatasinya)" yang ditulis oleh Nasution (2012). Selain itu, penelitian mengenai kecemasan berkomunikasi yang dilakukan pada program Magister Ilmu Komunikasi berjudul "Kompetensi
Komunikasi Antarbudaya (Analisis Hubungan Kecemasan dan Ketidakpastian Terhadap Kompetensi Komunikasi Antarbudaya Warga Jepang di Indonesia)" yang ditulis oleh Masril (2014).

Perbedaan antara penelitian yang dilakukan oleh peneliti dengan ketiga penelitian tersebut adalah pada acuan konsep atau teori mengenai kecemasan berkomunikasi yang digunakan, peneliti menggunakan konsep atau teori kecemasan berkomunikasi (communication apprehension) yang dikembangkan oleh James McCroskey, sedangkan ketiga penelitian tersebut menggunakan konsep atau teori kecemasan dan pengurangan ketidakpastian (Anxiety and Uncertainty Reduction Theory) yang dikembangkan oleh Charles Berger.

Penelitian sebelumnya menjadi bahan pustaka peneliti yang menggunakan penilaian diri (self-assessment) berbentuk kuesioner yang dikembangkan oleh McCroskey yaitu Personal Report of Communication Apprehension (PRCA) antara lain dilaksanakan oleh: 1) McCroskey, Richmond, Daly, dan Cox (1975) yang meneliti pengaruh kecemasan berkomunikasi pada ketertarikan antarpribadi seseorang, 2) McCroskey dan Andersen (1976) yang meneliti hubungan kecemasan berkomunikasi dengan capaian akademik pada mahasiswa universitas, 3) Buhr, Pryor, dan Sullivan (1991) untuk memeriksa hubungan antara kecemasan berkomunikasi dengan pemrosesan informasi oleh seseorang, 4) Keaten, Kelly, dan Pribyl (1997) mengukur kecemasan berkomunikasi pada murid-murid di enam sekolah negeri di Narashino-Jepang, 5) Meyer-Griffith, Reardon, dan Hartley (2009) untuk memeriksa hubungan pemikiran karir dengan kecemasan berkomunikasi, 6) Blume, Dreher, Baldwin (2010) yang meneliti efek kecemasan berkomunikasi dalam pusat penilaian, 7) 
Love (2013) pada mahasiswa di Universitas Ohio untuk mengetahui level kecemasan berkomunikasi mahasiswa.

PRCA merupakan salah satu instrumen penelitian non-tes yang paling banyak digunakan dalam studi ilmu komunikasi (Daly, 1986:25, Wrench, Brogan, McCroskey, dan Jowi, 2008:412) dan memiliki keunggulan yaitu; 1. skala seperti itu mudah dan murah untuk dikelola; 2. mereka bisa memanfaatkan tanggapan kecemasan di berbagai konteks komunikasi pada satu waktu; 3. skala Likert laporan diri yang terbukti sangat handal (McCroskey, 1970: 271).

Dari beberapa penelitian terdahulu, diketahui bahwa kecemasan berkomunikasi menyebabkan; 1) seseorang dianggap tidak positif terutama bila memiliki kecemasan berkomunikasi level tinggi (McCroskey dalam Anwar, 2009), dan 2) seseorang dianggap tidak responsif komunikatif, sulit untuk mengerti, tidak memiliki ketertarikan sosial dan seksual, tidak kompeten, tidak dapat dipercaya, tidak berorientasi pada tugas, tidak suka bergaul, tidak suka memimpin dan tidak produktif dalam kehidupan profesionalnya (Merrill; Mulac dan Sherman; McCroskey dan Richmond, dalam Anwar, 2009).

Intinya adalah bahwa kecemasan berbicara menghasilkan pengaruh yang negatif terhadap kehidupan ekonomi, akademis, politik, dan sosial individu (McCroskey dalam Anwar, 2009).

Berdasarkan latar belakang masalah diatas, maka perumasan masalah dalam penelitian ini adalah: Apakah ada pengaruh jenis kelamin, umur, dan tingkat perkuliahan terhadap kecemasan berkomunikasi pada mahasiswa jurusan akuntansi Politeknik Negeri Medan?

Tujuan penelitian ini adalah untuk mengetahui besarnya pengaruh jenis kelamin, umur, dan tingkat perkuliahan terhadap kecemasan berkomunikasi pada mahasiswa jurusan akuntansi Politeknik Negeri Medan.

\section{METODOLOGI PENELITIAN}

Penelitian ini merupakan penelitian kuantitatif dengan pendekatan korelasional. Variabel bebas dalam penelitian ini adalah jenis kelamin, usia, dan tingkat perkuliahan (semester perkuliahan), dan variabel terikatnya adalah kecemasan berkomunikasi yang diukur dengan PRCA24.

Kecemasan berkomunikasi (McCroskey dalam Love, 2013:35) mengkategorisasikan kecemasan berkomunikasi dalam tiga level yaitu level rendah dengan nilai total dari nilai setiap situasi kecemasan berkomunikasi antara 2458 , level menengah dengan nilai total antara 59-87, level tinggi dengan nilai total antara 88-120.

Personal Report of Communication Apprehension (PRCA) terdiri dari dua puluh empat pernyataan dengan jawaban bentuk skala Likert dengan kategori sebagai berikut:
- pernyataan perasaan saat berkomunikasi dalam kelompok sebanyak enam pernyataan;
- Pernyataan perasaan saat berkomunikasi dalam suatu rapat sebanyak enam pernyataan;
- pernyataan perasaan saat berkomunikasi berdua; dan
- pernyataan perasaan saat berkomunikasi di depan umum.

Populasi mahasiswa akuntansi jurusan akuntansi Politeknik Negeri Medan yang diteliti berjumlah 1.403 orang yang terdiri dari 176 orang laki-laki dan 522 orang perempuan pada Semester II, 209 laki-laki dan 496 perempuan pada semester IV. 
Jumlah sampel diambil dengan rumus Taro Yamane dengan tingkat kesalahan 5\% maka didapatkan jumlah sampel sebanyak 311 orang.

Pengambilan sampel dilakukan secara acak berdasar lapisan dengan mengundi nomor dari nama-nama mahasiswa semester II dan semester IV yang telah diurutkan sesuai abjad (A ke Z) dengan komposisi sesuai persentase perbandingan jumlah mahasiswa laki-laki dan perempuan maka didapat sampel dengan komposisi 39 orang laki-laki dan 116 orang perempuan mahasiswa semester II, 46 orang laki-laki dan 110 orang perempuan mahasiswa semester IV.

Mahasiswa yang menjadi sampel/responden kemudian dimintakan persetujuan dan diminta mengisi kuesioner PRCA.

Data yang dikumpulkan kemudian dianalisa secara korelasional dibantu dengan SPSS versi 16.

\section{HASIL DAN PEMBAHASAN}

Setelah dilakukan pengumpulan data kecemasan berkomunikasi pada mahasiswa jurusan akuntansi Politeknik Negeri Medan menggunakan kuesioner PRCA diketahui bahwa 119 orang memiliki kecemasan berkomunikasi level rendah, 189 orang memiliki kecemasan berkomunikasi level menengah dan 3 orang memiliki kecemasan berkomunikasi level tinggi (lebih rinci terlihat pada Tabel 1, Tabel 2 dan Tabel 3).

Tabel 1 Kecemasan Berkomunikasi Berdasarkan Jenis Kelamin

\begin{tabular}{|l|c|c|}
\hline \multirow{2}{*}{$\begin{array}{l}\text { Level } \\
\text { Kecemasan }\end{array}$} & \multicolumn{2}{|c|}{ Jenis Kelamin } \\
\cline { 2 - 3 } & $\begin{array}{c}\text { Laki-Laki } \\
\text { (orang/ } \\
\text { persentase) }\end{array}$ & $\begin{array}{c}\text { Perempuan } \\
\text { (orang/ } \\
\text { persentase) }\end{array}$ \\
\hline Rendah & $40 / 47,06 \%$ & $79 /$ \\
\hline
\end{tabular}

\begin{tabular}{|l|c|c|}
\hline & & $34,96 \%$ \\
\hline Menengah & $44 / 51,76 \%$ & $145 /$ \\
& & $64,16 \%$ \\
\hline Tinggi & $1 / 1,18 \%$ & $2 / 0,88 \%$ \\
\hline \multicolumn{2}{|l|}{ Sumber: hasil pengolahan SPSS (2016) }
\end{tabular}

Tabel 2 Kecemasan Berkomunikasi Berdasarkan Tingkat Perkuliahan

\begin{tabular}{|l|c|l|}
\hline \multirow{2}{*}{$\begin{array}{l}\text { Kevel } \\
\text { Becemasan }\end{array}$} & \multicolumn{2}{|c|}{ Tingkat Perkuliahan } \\
\cline { 2 - 3 } & $\begin{array}{c}\text { Semester 2 } \\
\text { (orang/ } \\
\text { persentase) }\end{array}$ & $\begin{array}{l}\text { Semester 4 } \\
\text { (orang/ } \\
\text { persentase) }\end{array}$ \\
\hline Rendah & $58 / 37,42 \%$ & $\begin{array}{l}61 / \\
39,10 \%\end{array}$ \\
\hline Menengah & $96 / 61,94 \%$ & $\begin{array}{l}93 / \\
59,62 \%\end{array}$ \\
\hline Tinggi & $1 / 0,65 \%$ & $2 / 1,28 \%$ \\
\hline \multicolumn{2}{|l|}{ Sumber: hasil pengolahan SPSS (2016) }
\end{tabular}

Tabel 3 Kecemasan Berkomunikasi Berdasarkan Umur

\begin{tabular}{|l|l|l|l|}
\hline \multirow{2}{*}{ Usia } & \multicolumn{3}{|l|}{ Level Kecemasan Berkomunikasi } \\
\cline { 2 - 4 } & Rendah & Menengah & Tinggi \\
\cline { 2 - 4 } & (orang/ persentase) & \multicolumn{2}{l|}{} \\
\hline 18 & $25 / 43,86 \%$ & $32 / 56,14 \%$ & $\begin{array}{l}0 / \\
0,00 \%\end{array}$ \\
\hline 19 & $56 / 39,44 \%$ & $85 / 59,86 \%$ & $\begin{array}{l}1 / \\
0,70 \%\end{array}$ \\
\hline 20 & $31 / 32,98 \%$ & $62 / 65,96 \%$ & $\begin{array}{l}1 / \\
1,06 \%\end{array}$ \\
\hline 21 & $5 / 38,46 \%$ & $8 / 61,54 \%$ & $\begin{array}{l}0 / \\
0,00 \%\end{array}$ \\
\hline 22 & $2 / 40,00 \%$ & $2 / 40,00 \%$ & $\begin{array}{l}1 / \\
20,00 \%\end{array}$ \\
\hline
\end{tabular}

Sumber: hasil pengolahan SPSS (2016)

Berger, McCroskey, Richmond (1984:137-138) menyatakan hasil pengukuran kecemasan berkomunikasi menggunakan Laporan Diri Kecemasan Berkomunikasi (PRCA) akan menghasilkan total nilai antara 24 sampai dengan 120 dalam tiga tingkatan yaitu;

1. Level rendah dengan total nilai antara 24-58, merupakan level dimana 
seseorang dengan kecemasan berkomunikasi yang paling sedikit, orang yang banyak berbicara dan mencari kesempatan berkomunikasi dengan orang lain.

2. Level menengah dengan total nilai antara 59-87. Jika total nilai antara 5965 maka seseorang akan merasakan kecemasan berkomunikasi yang lebih sedikit dibandingkan orang kebanyakan. Jika total nilai antara 6579, maka beberapa situasi akan membuat orang tersebut takut, namun dengan beberapa orang lain merasa nyaman. Jika total nilai antara 80-87, maka orang tersebut akan merasa lebih cemas berkomunikasi dari kebanyakan orang, beberapa situasi akan membuat seseorang cemas namun beberapa situasi tidak mengganggu orang tersebut.

3. Level tinggi dengan total nilai antara 88-120, orang tersebut merupakan orang yang jarang bicara, secara aktif menghindari situasi untuk berkomunikasi.

Setelah mendapatkan hasil penilaian kecemasan berkomunikasi tersebut, peneliti menguji secara korelasional apakah jenis kelamin, usia, maupun tingkat perkulian mempengaruhi level kecemasan berkomunikasi mahasiswa jurusan akuntansi Politeknik Negeri Medan.

Hipotesis pengujian korelasional yang peneliti ajukan adalah: H0: koefisien regresi tidak signifikan; H1: Koefisien regresi signifikan. Pengambilan keputusan berdasarkan probabilitas dengan ketentuan: jika signifikansi > 0,05 maka H0 diterima; jika signifikansi $<0,05$ maka $\mathrm{H} 0$ ditolak dan $\mathrm{H} 1$ diterima.

Pengujian korelasional menggunakan uji regresi didapatkan bahwa model regresi tidak bisa dipakai memprediksi kecemasan berkomunikasi, atau bisa dikatakan umur, jenis kelamin, dan tingkat perkuliahan tidak berpengaruh terhadap kecemasan berkomunikasi (dari uji ANOVA didapatkan nilai $\mathrm{F}$ hitung adalah 1,325 dengan tingkat signifikansi 0,266).

Hal ini sejalan dengan hasil penelitian Ford (2007) yang menyimpulkan bahwa tidak ada perbedaan signifikan antara tingkat kecemasan berkomunikasi dari laki-laki dan perempuan. Dengan diketahui bahwa kecemasan berkomunikasi pada mahasiswa jurusan akuntansi Politeknik Negeri Medan tidak dipengaruhi oleh jenis kelamin, umur dan tingkat perkuliahan, maka penanganan kecemasan berkomunikasi tidak dilakukan berdasarkan pemilahan jenis kelamin, umur, dan tingkat perkuliahan namun secara merata melalui pelatihan-pelatihan kepercayaan diri.

Meskipun tidak ada pengaruh jenis kelamin terhadap kecemasan berkomunikasi, namun pada Tabel 1 terlihat bahwa persentase mahasiswa perempuan yang memiliki kecemasan berkomunikasi level menengah $(64,16 \%)$ lebih besar dari level rendah (34,96\%), dibandingkan dengan mahasiswa laki-laki yang memiliki kecemasan berkomunikasi level menengah $(51,76 \%)$ dan kecemasan berkomunikasi level rendah 47,06\%). Hal ini sejalan dengan penelitian Malimabe (1997) yang menemukan bahwa level kecemasan berkomunikasi perempuan lebih tinggi dari laki-laki.

\section{KESIMPULAN}

Jenis kelamin, usia, dan tingkat perkuliahan tidak berpengaruh terhadap kecemasan berkomunikasi pada mahasiswa jurusan akuntansi Politeknik Negeri Medan. Kecemasan berkomunikasi dapat menjadi hambatan dalam berkomunikasi, oleh karena itu perlu penanganan untuk mengurangi level kecemasan berkomunikasi dengan pelatihan 
berkomunikasi dan peningkatan kepercayaan diri.

\section{DAFTAR PUSTAKA}

Anwar, Astrid Indi Dwisty (2009). Hubungan Antara Self-Efficacy Dengan Kecemasan Berbicara Di Depan Umum Pada Kecemasan Berbicara Di Depan Umum Pada Mahasiswa Fakultas Psikologi Universitas Sumatera Utara. Sumatera Utara: Skripsi, tidak dipublikasikan Universitas Sumatera Utara.

Berger, Bruce A., McCroskey, James C., dan Richmond, Virginia P. (1984). Communication Apprehension and Shyness. Dalam W. N. Tinally, R. S. Beardsley, \& F. R. Cultiss (Eds.), Communication in pharmacy practice: A practical guide for students and practitioners. Philadelphia: Lippincott Williams \& Wilkins.

Blume, Brian D., Dreher, George F., dan Baldwin, Timothy T. (2010). Examining the Effects of Communication Apprehension Within Assessment Centres. Journal of Occupational and Organizational Psychology, Vol. 83. Diunduh pada Maret 2016 melalui Library Genesis Database.

Buhr, Thomas A., Pryor, Burt, dan Sullivan, Mike (1991). A Further Examination of Communication Apprehension Processing. Cognitive Therapy and Research, Vol. 15 Nomor 4. Diunduh pada Maret 2016 melalui melalui Library Genesis Database.

Daly, John A. (1986). Communication Apprehension in The College Classroom. New Directions for Teaching and Learning, Vol 1986.
Diunduh pada Maret 2016 melalui Library Genesis Database.

Ford, Merilee (2007). Communication Apprehension: Visual Imagery and The Differences Between Men and Women. Utah: Tesis, Southern Utah University. Diunduh pada Maret 2016 melalui https://www.suu.edu.

Geçer, Aynur Kolburan \& Gümüş, Aynur Eren (2010). Prediction of Public and Private University Students' Communication Apprehension With Lecturers. Procedia Social and Behavioral Sciences 2, ScienceDirect. Diunduh pada Maret 2016 melalui Library Genesis Database.

Keaten, James, Kelly, Lynne, dan Pribyl, Charles B. (1997). Communication Apprehension in Japan: Grade School Through Secondary School. International Journal of Intercultural Relations, Vol. 21 No. 3. Diunduh pada Maret 2016 melalui Library Genesis Database.

Love, Jill Annette (2013). Communication Apprehension in The Classroom: A Study of Nontraditional Graduate Students at Ohio University. Ohio: Disertasi, Ohio University. Diunduh pada Maret 2016 melalui https://etd.ohiolink.edu.

Malimabe, Moshe Moses (1997). Communication Apprehension in Qwaqwa Secondary Schools. Potchefstroom: Mini-Dissertation, Potchefstroom University for Christian Higher Education. Diunduh pada Maret 2016 melalui http://dspace.nwu.ac.za.

Masril, Munzaimah (2014). Kompetensi Komunikasi Antarbudaya (Analisis Hubungan Kecemasan dan Ketidakpastian Terhadap Kompetensi Komunikasi Antarbudaya Warga Jepang di Indonesia). Sumatera 
Utara: Tesis, tidak dipublikasikan Universitas Sumatera Utara.

Matsuoka, Rieko; Rahimi, Ali (2011). The Possitive Effect of Conference Participation on Reducing L2 Communication Apprehension. Procedia Computer Science 3, ScienceDirect. Diunduh pada Maret 2016 melalui Library Genesis Database.

Meyer-Griffith, Katie, Reardon, Robert C. dan Hartley Sarah Lucas (2009). An Examination of The Relationship Between Career Thoughts and Communication Apprehension. The Career Development Quarterly, Vol. 58. Diunduh pada Maret 2016 melalui Library Genesis Database.

McCroskey, James C. (1970). Measures of Communication-Bound Anxiety. Speech Monographs, Vol 27 No. 4. Diunduh pada Maret 2016 melalui jamescmecroskey.com.

McCroskey, James C., Richmond, Virginia P., Daly, John A., dan Cox, Barbara G. (1975). The Effects of Communication Apprehension on Interpersonal Attraction. Human Communication Research, Vol. 2 No. 1. Diunduh pada Maret 2016 melalui jamescmecroskey.com.

McCroskey, James C., dan Andersen, Janis F. (1976). The Relationship Between Communication Apprehension and Academi Achievement Among College Students. Human Resource, Vo. 3. No. 1. Diunduh pada Maret 2016 melalui jamescmccroskey.com.

Nasution, Hery Bajora (2012). Kecemasan Berkomunikasi Antarpribadi dan Cara Mengatasinya (Studi Deskriptif Mengenai Kecemasan Pelamar Kerja Dalam Tes Wawancara Kerja dan Cara Mengatasinya). Sumatera Utara: Skripsi, tidak dipublikasikan Universitas Sumatera Utara.
Silitonga, Tabita (2011). Fenomena Komunikasi Antarpribadi Dosen Pembimbing dan Mahasiswa dalam Bimbingan Skripsi (Studi Kasus Kecemasan Berkomunikasi dan Ketidakpastian pada Mahasiswa USU). Sumatera Utara: Skripsi, tidak dipublikasikan Universitas Sumatera Utara.

Wrench, Jason S., Brogan, Shannon M., McCroskey, James C., dan Jowi, Doreen (2008). Social Communication Apprehension: The Intersection of Communication Apprehension and Social Phobia. Human Communication, A Journal of the Pacific and Asian Communication Association, Vol. 11 No. 4. Diunduh pada Maret 2016 melalui jamescmccroskey.com.

Sumber website (non buku/majalah):

"Ini 12 Sektor Utama Dalam MEA 2015" Diakses Maret 2016. http://www.beritasatu.com/ekonomi/ 173987-ini-12-sektor-utama-dalammea-2015.html. 